\title{
Executive Pay Composition and Corporate Financial Health Maximisation
}

\author{
Dr. Stanley OGOUN Emmanuel ATAGBORO \\ Department of Accountancy, Management Sciences, Niger Delta University, \\ Amassoma, Bayelsa State, Nigeria
}

\begin{abstract}
This study examined the relationship between executive pay composition and corporate financial health maximisation in Nigeria. Secondary data was obtained from the annual reports and accounts and Nigerian Stock Exchange Fact-book during the period 2008-2017 and ordinary least square was employed in the analysis of data. Net interest margin, return on asset and return on equity were operationalized as proxies for corporate financial health maximisation while bonus scheme as proxy for executive pay composition. The study found an executive pay package comprising of a bonus scheme is likely to influence managers to behave in a manner that would ensure the overall wellbeing of the organization. The study recommends that a bonus scheme should be a major component of executive composition as not a way of managing agency cost but also as a tool for instigating managerial behaviour that would enhance overall wellbeing of the organization.
\end{abstract}

Keywords: Executive pay composition, Corporate financial health maximisation, Bonus scheme

DOI: $10.7176 /$ RJFA/10-22-05

Publication date: November $30^{\text {th }} 2019$

\section{Introduction}

Corporate scandals involving Enron, Anderson, Adelphia among others confirmed a requirement for highly reputable financial reporting and considerable attention to diverse factors that may have effect on financial reporting. From an agency theory viewpoint, Dang (2004) opines that unqualified (audited) financial statements are a monitoring technique to provide assurance for users of financial information. This information is fundamental not only to investors but to all users of financial statement in assessing the reputability and the financial health of such reports so as to maximise the wealth of the corporation. Reputability of financial reports implies that users of accounting or financial reports should ascertain that such report is trustworthy, reliable, have integrity and sincerity in reporting all activities of the organization. In addition, it has been found that large compensation given to executives may be connected with corporate scandals that rocked Enron, World.com and a host of other collapsed firms in the past and recent times.

Executive pay composition is a complex and contentious subject. The high level of chief executive officer (CEO) pay in most developed and developing countries have motivated an intense concern about the nature of the pay-setting process and the output it produces. Some scholars argued that the enormous pay packages given to top managements have contributed to the collapse of firms. Executive compensation (also executive pay), is financial compensation received by an officer of a firm. Executive pay is usually a combination of salaries, bonuses, shares of and/or call options on a firm's stock and benefits, ideally configured to take into cognizance government regulations, tax law, the needs of the firm and the executive, and rewards for performance (Maijoor \& Vanstraelen, 2006).

The executive compensation literature has experienced tremendous growth in recent years, and so as our understanding of pay practices. Yet, numerous important questions remain unanswered. The causes of the noticeable regime change in CEO compensation that occurred during the 1970s remain essentially unknown. The relative importance of rent extraction and optimal contracting in ascertaining pay for CEO is still to be ascertained, and even lower degree is known about the causal effects of Executive pay on behaviour and firm value. Proffering solutions to these problems will require a mixture of new theory predictions, the creative use of exogenous changes in the contracting environment, and new data from countries, prior decades, and different types of firms. The progress made by recent studies on all these dimensions is cause for optimism and suggests that answers may not be far off (DeFond, \& Jiambalvo, 1991 and Francis, 2004).

The flaw of corporate governance is conceivably the most important dynamic blamed for the corporate disappointment and consequences from the economic and corporate crises. A lot have to be done to improve the financial health of firms, the restoration of resources devoted to audit function, and improved corporate governance policies. Concerns have also emerged about increased executive pay and Economist (2004) notes that there are questions about the increased executive pay. Quite a few studies have attempted to measure a direct link with executive pay composition and the corporate wealth maximisation in developed countries (Geiger \& Raghunandan, 2002; Brown \& Heinzl, 2004), while there are little or no studies on the impact of executive pay composition on the corporate financial health maximisation, using some financial accounting variables such as return on equity, assets, net interest margin and executive bonus in Nigeria. This study 
investigated how executive pay composition affects the credibility of financial reports among deposit money banks in Nigeria. Therefore, our study extends and contributes to the body of research using deposit money banks at NSE to investigate the likely effect of executive pay composition on the corporate financial health maximisation.

\section{Literature Review}

\subsection{Return on Assets, Return on Equity and Net Interest Margin}

Return on Assets (ROA), return on equity (ROE) and net interest margin (NIM) are used to interpret (profitability, leverage and liquidity) the financial statements of companies. Financial statements are usually prepared in accordance with Financial Reporting Standards of Nigeria and International Financial Reporting Standards (IFRSs) such as SAS 1, 2 and IAS 1. Such financial statements include financial position, profit or loss, changes in equity, cash flows, notes to the accounts and comparative financial position. Other reports to be included in the case of Nigeria and in accordance with Companies and Allied Matters Act (CAMA) 1990, as amended, are Directors report, auditors report and audit committee report. These statements and reports are prepared and presented to the various stakeholders or users that will enable them make informed judgment and economic decisions. NIM, ROA and ROE are essential ratios used for evaluating how effectively and efficiently a firm's executives manage the capital entrusted to them.

Net Interest Margin (for banks and other financial institutions) also called gross margin or gross profit margin (for non-financial corporations) usually expressed as a percentage, measures or evaluates the difference between the interest earned by banks/financial institutions and the amount of interest paid out to lenders, relative to the amount of their interest-earning assets (Igben, 2017). Return on Assets (ROA) and Return on Equity (ROE) are components of return on capital employed that measure and evaluate how executives effectively and efficiently manage the organisations' financial and capital resources under their custody. ROE is a test of the optimal use of a corporation's financial resources by the management (executives) in order to determine whether the organisation is growing at a feasible region or not. On the other hand, ROA is profitability test ratio that measures the return or profit earned from one naira invested in the company's total assets. The assets comprise non-current and current categories or classification.

\subsection{Theoretical Foundation}

This study is theoretically anchored on the following stakeholders' theory, stewardship theory and legitimacy theory as highlighted below.

\subsubsection{Stakeholder's Theory}

The stakeholder' theory also referred to as corporate wealth maximisation(CWM) is an alternative to the shareholders' wealth maximisation with the view that a firm is a coalition of different groups such as the equity and preference shareholders, creditors, employees, suppliers, customers, government, media and the community (Oye, 2014). The theory is of the assertions that stakeholders should be acknowledged and paid minimum return because the back-off of their contributions and services may lead to the collapse of the entity. That is any excess wealth created by the entity should be and is the subject of bargaining between the stakeholders. This theory is acknowledged because in reality, the traditional objective of the sole shareholders' wealth maximisation is too simplistic, defective and incorrect. That is, the objectives of most firms are financial and non-financial.

The non-financial objectives are to provide for the welfare of employees and management, contribute to the welfare of the society and to give the highest quality services to customers. These objectives are not to cancel the financial objectives of the corporation but to add more value to it. Meaning, the financial objectives should be compromised in order to satisfy other stakeholders other than the shareholders. Whether with the aim of maximising shareholders'/stakeholders' wealth, the executives (management) have a major role to play. That is, the effect of the pay composition of the executives on the returns accruing to the corporation (stakeholders) has created a big concern to firms, scholars, researchers and the general public.

\subsubsection{Stewardship Theory}

From the views of Donaldson and Davis (1991), stewardship theory suggests that there is no intrinsic or general dilemma of executive motivation. On the basis of this theory, executive manager, far from being an opportunistic dawdler, essentially desires to do a good job, to be a good steward of the corporate assets. According to stewardship theory, performance variations arise, not from inner motivational tribulations among executives, but from whether the structural situation in which the executive is located facilitates effective action by the executive (Donaldson \& Davis, 1991). Agency theory provides a valuable way of explaining connections where the parties' interests are at odds and can be brought more into coalition via proper monitoring and a wellplanned compensation system (Donaldson and Davis, 1991). According to the authors however, to explain other types of human behaviour, additional theory is needed. Following Davis et al. (1997), in stewardship theory, the model of human is based on a steward whose behaviour is ordered such that pro-organizational, collectivistic behaviours have higher utility than individualistic, self-serving behaviours. The stewardship theory defines 
situations in which managers are not motivated by individual goals. They are rather stewards whose motives with the objectives of their owners are aligned. "Stewardship theorists assume a strong correlation between the success of the organization and the principal's contentment.

A steward protects and maximizes shareholders' wealth via firm performance, because, by so doing, the steward's utility functions are greatly maximized" (Davis et al., 1997). Stewards are driven by fundamental rewards, such as reciprocity and mission alliance, rather than solely extrinsic rewards. The steward, as opposed to the agent, places greater value on joint rather than personal goals; the steward understands the firm's accomplishment as his own achievement. From the views of Davis et al. (1997), the major disparity between agency theory and stewardship theory lies in the assumptions about human nature. From the agency theory perspective, people are individualistic, utility maximizes. In respect of stewardship theory, people are collective self-actualizers who achieve satisfaction via achievement of organization. The agency model assumes a principal-agent relationship in which differing motives and information asymmetry lead to concern about the reliability of information. Within the agency theory, the role of the audit is to reinforce trust and confidence in financial reporting.

Unlike the agency theory, the stewardship theory suggests that no innate, universal problem of executive drive exists. The model of human is based on a steward whose behaviour is pro-organizational and collectivistic. Based on the basic views of stewardship theory, the implementation of the monitoring mechanisms and engaging audit services in order to secure the reliability of information is needless. But, within stewardship theory an audit could be of importance as a means of assisting the executive's stewardship. According to stewardship theory, the executive director places greater worth on collective rather than individual goals. The executive is driven to be a good steward of corporate assets and an audit could help to express good stewardship. Displaying unqualified (audited) financial statements, the steward expresses truth and fairness of financial and non-financial performances.

\subsubsection{Legitimacy Theory}

This theory posits that firms incessantly seek to ensure that they are perceived as functioning within the bounds and norms of their respective societies, that is, they attempt to ensure that their activities are perceived by external parties as being 'legitimate' (Deegan and Unerman, 2006). Legitimacy theory relies upon the conception of a 'social contract' between the organization and the society in which it operates. "The concept is used to illustrate the multitude of implicit and explicit expectations that society has about the firm in which way they should conduct its operations". Legitimacy from society's perspective and the right to operate goes hand in hand.

Society allows the organization to continue operations to the extent that it generally meets their expectations (Deegan \& Unerman, 2006). Legitimacy theory holds that management will adopt specific strategies to assure the society that the organization is complying with the society's values and norms, for example the disclosure of information in annual reports. This theory is one example of many theoretical perspectives, adopted in explaining and predicting accounting practice. Irrespective of the fact that the research is about executive pay composition and the corporate financial health maximisation, it is viable considering the legitimacy theory. The essence is about information disclosure, accountability, value relevance and the information needs of users. Legitimacy theory could also be signalled as a clarification of the need for an independent opinion on the truth and on the fairness of the company's' wealth or health reporting.

Given that the principals may lack trust in their agents, they need to establish some mechanisms to make sure that principals are doing what they are engaged to do. This is an attempt to achieve via two fundamental groups of governance mechanisms: better alignment of incentives and monitoring. According to the standard agency theory, shareholders (principals) try to mitigate the conflict of interest by designing optimal compensation packages to motivate the executives (agents). Efficient incentive contract can substitute the lack of shareholder monitoring and reduce agency costs. As Frydman and Jenter (2010) put it, "the extensive use of incentive compensation and the huge cross-sectional differences in managerial contracts would make modest sense if compensation had no effect on CEO behaviour". However, contracts designed to align incentives have well-known limitations. Firstly, contracts can never be complete and, secondly, agents typically control both effort and (at least to some degree) the reporting of their effort (firm performance). Because of the persistent differences between incentives of owners and agents monitoring mechanisms such as auditing are put in place to monitor both agents and contracts (Jensen \& Meckling 1976).

\subsection{Empirical Evidence}

In a recent study, Hribar and Yang (2010) consider excess audit fees as a reflection of overall accounting system quality and argue that as auditors have access to opaque information concerning internal controls, financial reporting process, and management, they have the opportunity to evaluate the overall accounting system quality and charge a fee premium from riskier clients. Excess audit fees should hence capture the auditor's private assessment of firm complexity and risk, and the quality of firm-specific accounting system. There are two 
opposing views relating to the research on executive pay composition contracts that are relevant to the present study.

On the one hand, some argue that considerable executive pay packages are a result of optimal contracting in a competitive market for managerial talent. Specifically, due to the scarcity of managerial talent in the labour market, more qualified managers with higher marginal productivity should receive higher compensation (see, e.g. Fama 1980; Rosen 1982).

Hamidah, (2015) investigated EVA, ROCE, ROE, and EPS as method of assessment of financial performance and its effect on shareholders' wealth: evidence from banks listed at Indonesian Stock Exchange. The study involved 30 banks which went public. Purposive sampling, using the data in the form of annual financial statements from 2011 to 2013 was used. It utilized the simple regression analysis method, namely by using the F-test and t-test, in order to determine the effect of the financial performance measurement results with the level of significance is $(\alpha)=0: 05$. The results of the study partially, shows that the calculation of EVA during the period yielded positive results, although not significant in explaining the Shareholders' Wealth, and is proven that the EVA assessed cannot predict the value-added. Measurement of ROCE and EPS depict positive and significant impact on shareholders' wealth while analysis of ROE shows negative effect on shareholders' wealth

Aduda (2011) did a study on the relationship between executive compensation and firm performance in the Kenyan banking sector. The general objective of the study was to measure the relationship between executive compensation and firm performance among the commercial banks listed at the Nairobi Stock Exchange by adopting a causal research design. The target population comprised of the nine commercial banks listed at the Nairobi stock exchange as at December 2008. A census survey was conducted of the listed commercial banks. The study employed secondary data which was obtained from the financial statements of the commercial banks. A multiple regression model was used to analyze the data. In analyzing the effect of compensation structure on firm performance, only realized compensation was considered. Regression results for the whole banking sector revealed that size is negatively and significantly related to the determination of executive pay. This is contrary to the findings of Rosen (1990) that found pay-for-firm size elasticity to be positive and the estimated elasticity was not significantly different from 0.3 that is, $\beta=0.3$. In the study, the overall sensitivity of executive compensation to bank size was -0.0238 , that is, $\beta=-0.0238$. With regard to firm performance, two explanatory variables were tested namely return on assets (ROA) and relative performance to industry ROE which was essentially used to identify the firms that were able to register above industry average returns on equity. Thus the study found a negative non-significant relationship between executive compensation and performance of commercial banks in Kenya.

Gathua, Ngumi and Kiragu (2013) examined the relationship between executive compensation and risk among commercial banks in Kenya. This study used descriptive survey research design. Data on executive remuneration was the average of four years (2008-2011) while primary data on the dependent variables was collected through the questionnaire during the period from July 2012 and concluded in August 2012. Simple linear regression model was used to analyse the data. The responses on the likert scale questionnaire were coded and input in the SPSS software. A simple regression model was used to measure the relationship between the independent variable and the dependent variables which are explained in the model. The findings of the regression analysis show that executive compensation explains a very small variation of $0.07 \%$ of the changes in the non-performing loans among Kenyan commercial banks.

In concluding empirical literature, it is very clear that there are little or no studies on executive pay composition on the corporate financial health maximisation in Nigeria. That is, the study investigated how executive compensation affects the corporate wealth maximisation among deposit money banks in Nigeria using some financial accounting independent variables such as return on equity, assets, net interest margin and a dependent variable, executive bonus in Nigeria.

\section{Materials and Methods}

This study investigates the impact of executive pay composition and the corporate financial health maximisation in Nigeria. In carrying out this study, the quantitative research design was employed. The quantitative research design focuses primarily on the construction of quantitative data, and quantitative data is a systematic record that consists of numbers constructed by researcher utilizing the process of measurement and imposing structure. The population considered in this study is the total number of Deposit Money Banks (DMBs) in Nigeria. The total number of Deposit Money Banks (DMBs) as at December 31, 2017 in the country stood at fifteen (15) (Central Bank of Nigeria, 2017). A total of five Deposit Money Banks (DMBs) constitutes the sample size. The justification for the choice of the five (5) Deposit Money Banks (DMBs) was based on banks that have the data needed for the study.

The study used secondary data. The data collected for the study comprised accounting data extracted primarily from the Published Annual Reports and Accounts of the Deposit Money Banks (DMBs). The data 
include net interest margin, return on asset and return on equity figure extracted from the annual reports and accounts of the selected banks. These data have been deemed valid by standard and recognized bodies that regulate Deposit Money Banks (DMBs) activities in Nigeria.

The method of data analysis was based on the published annual reports for year 2008-2017, which were prepared by the Deposit Money Banks (DMBs) and therefore, net interest margin, return on asset and return on equity as at December 31, 2008 - 2017 were obtained. In order to determine the impact of executive pay composition (executive bonus) on the corporate financial health maximisation, the Ordinary Least Squares (OLS) estimation technique was employed. However, the analysis was done via STATA 13.0 Version. A simple regression model was formulated based on each respective variable (dependent and independent variables). The independent variables are net interest margin, return on asset and return on equity while the dependent variable is executive bonus. The data for the analysis was done using the periods 2008-2017 by adopting regression analysis. The simple regression was estimated for each dependent variable. The general model is given below:
$E X C O M P=$
$F(N I M, R O E, R O A)$
Eq. 1 below:

Equation 1 was estimated in its implicit form and it is further expressed in its explicit form as in equation 2

$E X C O M P_{i t}=a_{0}+b_{1} N_{I M} M_{i t}+b_{2} R O E_{i t}+b_{3} R O A_{i t}+U_{t} \quad E q .2$

Where: NIM = Net Interest Margin of sampled banks at time $t ;$ ROA $=$ Return on Asset of sampled banks at time $t ; R O E=$ Return on Equity of sampled banks at time $t ; E X C O M P \quad=$ Executive bonus of sampled banks at time $t ; a, b_{i t}=$ Regression Coefficients; $U_{t}=$ Error term

Statistical data analysis for this study was conducted by running a multiple regression using Ordinary Least Square (OLS) estimation technique to test the formulated hypotheses. To ensure that the regression analysis is valid and that generalizations can be made about the population based on regression analysis conducted on the sample, four main assumptions were complied with. These assumptions are linearity, equal variance (homoscedasticity), independence of residuals and normality of residuals. Compliance with these aforementioned assumptions were achieved by adopting the following tools of analysis: The F-statistics, Pearson's correlation coefficient, Durbin-Watson statistics and the level of significance arising from the regressions are used to investigate and test the predictive ability of each individual regression models. The Durbin-Watson statistic was used to detect serial correlations between the residuals. The t-statistics was used to test the significant contribution from each predictor to the regression model. The coefficient of determination (adjusted $\mathrm{R}^{2}$ ) measures the strength of the relationships between the dependent variable and the predictors in the prediction model by indicating the proportion of the variance in the dependent variable statistically explained by the independent variables in the regression model The higher is the adjusted $\mathrm{R}^{2}$ coefficient, the stronger the explanatory powers or predictive ability of the model.

\section{Data and Results}

Table 1: Descriptive Statistics of the Variables of the Study

\begin{tabular}{llrrrr}
\hline Variable & Obs & Mean & Std. Dev. & Min & Max \\
\hline nim & 138 & 60.64493 & 11.33672 & 21 & 85 \\
retoa & 138 & 1.044565 & 3.936938 & -29.64 & 9.54 \\
retoe & 138 & 6.302971 & 49.88348 & -394.32 & 230.23
\end{tabular}

Source: STATA 13.0 Version, 2018

Table 1 above shows the descriptive statistics of the variables (dependent variables: Net Interest Margin (NIM), Return on Asset (ROA) and Return on Equity (ROE) during the period under review. From the results, it was observed that NIM recorded a mean and standard deviation of 60.64493 and 11.33672 respectively. This implies that the mean can deviate from both sides by $60.7 \%$. The minimum and maximum values reported during the period under review were $\$ 21$ and $\$ 85$. This implies that the highest and lowest NIM of the banks under review was $\$ 21$ and $\$ 85$ respectively. The highest NIM was recorded by Diamond Bank Plc in 2011 and the lowest by Wema Bank PLC in 2008.

Furthermore, ROA recorded a mean and standard deviation of 1.044565 and 3.936938 respectively. This indicates that the mean can deviate from both sides by $1.05 \%$. The minimum and maximum values reported during the period under review were -29.64 and 9.54 respectively. The lowest ROA was recorded by Wema Bank PLC in 2008 while the highest by Union Bank of Nigeria in 2010. Also, ROE recorded a mean and standard deviation of 6.302971 and 49.88348 respectively. The implication is that the mean can deviate from both sides by $6.3 \%$. The minimum and maximum values reported during the period under review were -394.32 and 230.23 respectively. The lowest ROE was recorded by Wema Bank PLC in 2012 while the highest by Wema Bank in 2008 
Table 2: Collinearity Diagnostic Test \& ANOVA Results for Net Interest Margin

\begin{tabular}{llll}
\hline Eigenvalue & .277 & Condition Index & 2.495 \\
\hline & \multicolumn{4}{c}{ ANOVA } \\
f-statistic & 17.80 & Probability & 0.0006 \\
\hline
\end{tabular}

The result of the Max-Eigenvalue collinearity diagnostic test showed that the errors are normally distributed. The f-stat (17.80) and p-value (0.0006) indicating that there is significant linear relationship between the independent variable (Net Interest Margin) and dependent variable (Executive Pay).

Table 3: Collinearity Diagnostic Test \& ANOVA Results for Return on Asset

\begin{tabular}{llll}
\hline Eigenvalue & .277 & Condition Index & 2.495 \\
\hline f-statistic & 13.51 & Probability & 0.0327 \\
\hline
\end{tabular}

Source: STATA, 13.0 Version, 2018

The result of the Max-Eigenvalue collinearity diagnostic test showed that the errors are normally distributed. The f-stat (13.51) and p-value (0.0327) indicated that there is significant linear relationship between the independent variable (return on asset) and dependent variable (executive Pay).

Table 4: Collinearity Diagnostic Test \& ANOVA Results for Return on Equity

\begin{tabular}{|c|c|c|}
\hline Eigenvalue & Condition Index & 2.495 \\
\hline \multicolumn{3}{|c|}{ ANOVA } \\
\hline f-statisticic 13.0 Version, ${ }^{16} 0^{\circ} 18^{3}$ & Probability & 0.0494 \\
\hline
\end{tabular}

The result of the Max-Eigenvalue collinearity diagnostic test showed that the errors are normally distributed. The f-stat (16.13) and p-value (0.0494) indicate that, there is significant linear relationship between the independent variable (return on equity) and dependent variable (executive Pay).

Table 5: Regression Result

\begin{tabular}{|c|c|c|c|c|}
\hline Source & SS & $\mathrm{df}$ & MS & Number of obs $=$ \\
\hline Model & 1823.29628 & 2 & 911.648138 & $\mathrm{~F}(2,135)$ \\
\hline Residual & 15784.0988 & 135 & 116.91925 & $\begin{array}{l}\text { Prob > F } \\
\text { R-squared }\end{array}$ \\
\hline Total & 17607.3951 & 137 & 128.521132 & $\begin{aligned} \text { Adj R-squared } & =0.780 \\
\text { Root MSE } & =10.813\end{aligned}$ \\
\hline excomp & Coef. & Stf. Err. & $\mathrm{P} / \mathrm{t} /$ & [958 Conf. Interva] \\
\hline rotoe & 2.965354 & 2.175841 & 4.360 .001 & 7.268498 \\
\hline retoa & 10.43448 & 2.693918 & 0.000 & 5.106741 \\
\hline nim & 28.74772 & 12.20638 & $9.36 \quad 0.020$ & 4.60725 \\
\hline cons & 30.14061 & 23.27201 & $3.30 \quad 0.007$ & 76.16549 \\
\hline
\end{tabular}

Source: STATA 13.0 Version, 2018

From the evaluation of the regression result, we find that $\mathrm{R}^{2}$ adjusted is .780 which suggests $78.0 \%$ explanatory ability of the estimation for the systematic variation in the dependent variable (Net Interest Margin: NIM) with an adjusted value of .22 (22.0\%). The unexplained variation is $78.0 \%(1-.780)$. The evaluation of the slope coefficients of the explanatory variables revealed the existence of positive relationship between executive pay composition and corporate financial health maximisation measures ( $R O E=2.965354),(\mathrm{ROA}=10.43448)$ and Net Interest Margin (NIM: 30.14061) among Nigerian banks as depicted by the slope coefficients.

The result in table 5 above is further supported by the computed t-values for $\mathrm{ROE}=(4.36)$ which is greater than t-tabulated (1.660) suggesting that ROE is a major determinant of executive composition. Meaning there is significant correlation between executive pay (executive bonus) and the corporate financial health maximisation (return on equity). Besides, the result in table 5 above is further supported by the computed t-values for ROA $=$ (7.87) which is greater than t-tabulated (1.660) suggesting that ROA is a major determinant of executive compensation. This implies that there is significant relationship between executive pay (executive bonus) and corporate financial health maximisation (return on asset). Furthermore, the result in table 5 above is further supported by the computed t-values for ROA $=(9.36)$ which is greater than t-tabulated (1.660) suggesting that NIM is a major determinant of executive compensation. This shows that there is significant relationship between executive pay (executive bonus) and corporate financial health maximisation (net interest margin). 


\section{Conclusion and Policy Implication}

The aim of the study was to examine executive pay composition (using a single variable approach) and corporate financial health maximisation in Nigeria. Executive pay composition was operationalized using bonus scheme while corporate financial health maximisation was operationalized using the indices of ROA, ROE and NIM. From the result of the inferential tests conducted it can be inferred that an executive pay package comprising of a bonus scheme is likely to influence managers to behave in a manner that would ensure the overall wellbeing of the organization. This conclusion is quite informative and has serious implications managing the agency theory construct.

Given the fact that managers often have conflicting interest with shareholders and are therefore likely to exhibit behavioural tendencies that would optimize their utility at the expense of that of stakeholders with obvious negative implications for corporate wellbeing, the bonus component which is predicated on meeting key performance index have been identified as a reward systems that motivates performance. A bonus scheme like stock option increases commitment to an organization as it is perceived as a commendation for optimal performance (meeting or exceeding KPI, whichever one applies). Our thinking is that the potential of a bonus compensation scheme in motivating employee performance (a scheme is copious applied in rewarding target based compensation plans) should also apply to those at the managerial level.

Following from the conclusion reached and the implications, we recommend that a bonus scheme should be a major component of executive pay composition as not a way managing agency cost but also as a tool for instigating managerial behaviour that would enhance or optimize corporate financial health maximisation by implication the overall wellbeing of the organization.

\section{References}

Abbott, L. J., Parker, S., Peters, G. F., \& Raghunandan, K. (2003). An empirical investigation of audit fees, nonaudit fees, and audit committees. Contemporary Accounting Research, 20(2), 215-234.

Aduda J (2011). The relationship between executive compensation and firm performance in the Kenyan banking sector. Journal of Accounting and Taxation 3(6)130-139.

Ashbaugh, H., \& Warfield, T. D. (2003). Audit as a corporate governance mechanism: Evidence from the German market. Journal of International Accounting Research, 2, 1-21.

Barnes, L. (2008). Banking sector governance: lessons from hong kong listed banks--A three-year perspective. ICFAI Journal of Corporate Governance, 7(1), 22-35.

Becker, C. L., Defond, M. L., Jiambalvo, J., \& Subramanyam, K. R. (1998). The effect of audit quality on earnings management. Contemporary Accounting Research, 15(1), 1-24.

Brown, K., and M. Heinzl. (2004). Nortel board finds accounting tricks behind '03 profits. Wall Street Journal 9(2) 361-382.

Carcello, J. V., Hermanson, D.R., Neal, T. L., \& Riley Jr, R. A. (2002). Board characteristics and audit fees. Contemporary Accounting Research, 19(3), 365-384.

Chung, R., Firth, M., \& Jeong-Bon, K. (2003). Auditor conservatism and reported earnings. Accounting \& Business Research, 33(1), 19-32.

Davies, M.B. (2007), Doing a successful research project. Using qualitative or quantitative methods, Palgrave Macmillan

Dechow, P. M., Ge, W. \& Schrand, C. (2010). Understanding earnings quality: A review of the proxies, their determinants and their consequences. Journal of Accounting and Economics, 50, 344-401.

DeFond, M. L., \& Jiambalvo, J. (1991). Incidence and circumstances of accounting errors. Accounting Review, 66(3), 643-655.

DeFond, M. L., \& Jiambalvo, J. (1993). Factors related to auditor-client disagreements over income-increasing accounting methods. Contemporary Accounting Research, 9(2), 415-431.

Desender, K. A. (2010). Essays on ownership structure, corporate governance and corporate finance. Universitat Autònoma de Barcelona, Barcelona.

Donaldson, L. and J.H. Davis (1991), Stewardship theory or agency theory: CEO governance and shareholder returns, Australian Journal of Management, 16, (1), 49-65 46

Dunn, K. A., B. W. Mayhew and S. G. Morsefield. 2000. Disclosure quality and auditor choice. Working paper. CUNY - Baruch.

Eisenberg, T., Sundgren, S., Wells, M.T., 1998. Larger board size and decreasing firm value in small firms. Journal of Financial Economics 48, 35-54.

Fama E (2005), 'Agency problems and the theory of the firm', Journal of Political Economy, 88, (2), $288-307$.

Francis, J.R., (2004). What do we know about audit quality?. The British Accounting Review 36, $345-368$.

Francis, J. R., \& Krishnan, J. (1999). Accounting accruals and auditor reporting conservatism. Contemporary Accounting Research, 16(1), 135-165.

Francis, J. R., Maydew, E. L., \& Sparks, H. C. (1999). The role of big 6 auditors in the credible reporting of 
accruals. Auditing, 18(2), 17.

Gathua P. K., Ngumi P., and Kiragu D N.(2013). The relationship between executive compensation and risk among commercial banks in Kenya. Prime journal Vol. 2(2), 204-212.

Geiger, M., and K. Raghunandan (2002). "Auditor tenure and audit reporting failures". Auditing: A Journal of Practice \& Theory, 21 (1): 67-78.

Giroud, X., H.M. Mueller (2011). Corporate governance, product market competition, and equity prices. Journal of Finance, 66(2), 563-600.

Guedhami, O., Pittman, J. A., \& Saffar, W. (2009). Auditor choice in privatized firms: Empirical evidence on the role of state and foreign owners. Journal of Accounting \& Economics, 48(2/3), 151-171.

Hartarska, V. (2009). The impact of outside control in listed companies. Managerial Finance, 35(12), 1-13.

Hermalin, B. E., Weisbach, M.S., (1998). Endogenously chosen boards of directors and their monitoring of the CEO. American Economic Review, 88 (1), 96-118.

Hribar, P. \& Yang, H. (2010). Does CEO overconfidence affect management forecasting and subsequent earnings management? Journal of Accounting and Public Policy.

Igben, R. O. (2017). Advanced financial accounting made simple. ROI Publishers, Isolo, Lagos, Nigeria.

Leuz, C., Lins, K. V., \& Warnock, F. E. (2009). Do foreigners invest less in poorly governed firms? Review of Financial Studies, 22(8), 3245-3285.

Lin, J. W., \& Hwang, M. I. (2010). Audit quality, corporate governance, and earnings management: A MetaAnalysis. International Journal of Auditing, 14(1), 57-77.

Maijoor, S. J., \& Vanstraelen, A. (2006). Earnings management within Europe: the effects of member state audit environment, audit firm quality and international capital markets. Accounting \& Business Research, 36(1), 33-52.

Manos, R., \& Yaron, J. (2008). Key Issues in assessing the performance of listed companies institutions. Working Paper - The College of Management, Israel.

Mersland, R. and R. O. Strom (2009). Performance and governance in listed companies institutions. Journal of Banking \& Finance 33(4), 662-669.

Mersland, R. and R. O. Strom (2011). Board capture or firm complexity? Choice of directors in listed companies institutions. Working Paper.

Oye, A (2014). Financial management. El-Toda Ventures LTD, Mushim, Lagos, Nigeria

Shelton, S. W., Koehn, J. L., \& Sinason, D. (2009). Influence of business risk assessment on auditors' planned audit procedures. 